UDC 128

\title{
PHILOSOPHIC AND ANTHROPOLOGICAL ANALYSIS OF MAN'S FEAR BASES IN MODERN CULTURE
}

\author{
Andrey M. Roudenko, Lyudmila E. Kireeva \\ Institute of service and entrepreneurship (branch) of Don state technical university \\ Rostov-on-Don, Russian Federation \\ science-almanac@mail.ru
}

It is presented a philosophical and anthropological analysis of the basic foundations of human fear in modern culture. The underlying foundation of the fear of man is ambivalent: fear, on the one hand, protects a person from danger and contributes to the playful person, but, on the other hand, fear limits human comprehension of being, constrains its activity. Fear either mobilizes or slows down human behavior: fear can manifest asthenic reaction (numbness and tremors, utter confusion), sthenic reaction (panic), or sthenic excitement. Fear of death causes a person to avoid situations that pose a threat to his life. Fear arises from a person in connection with the objectification of anxiety under the influence of imaginary or real dangers. It is experienced holistically by the person on various levels: physical, emotional, cognitive and behavioral. The causes of fear can also be classified into several groups, among which mention should be made of natural, individual and socio-cultural. Fear is inherent in all higher mammals and perform the necessary biological function associated with the response to the situation that causes the danger. Irrational fear is man's fear of himself, in front of hidden in the unconscious destructive impulses. Fear appears as one of the mechanisms for the formation of social character - imparting qualities of the person considered necessary in this society, and the limitations of those behavioural manifestations that are considered undesirable.

Key words: fear, personality, culture, people, society, philosophy, philosophical anthropology.

\section{[Руденко А.М., Киреева Л.Е. Философско-антропологический анализ базовых оснований чело- веческого страха в современной культуре]}

Представлен философско-антропологический анализ базовых оснований человеческого страха в современной культуре. Базовые основания страха человека двойственны: страх, с одной стороны, защищает человека от опасности и способствует жизнеутверждению человека, но, с другой стороны, страх ограничивает человеческое постижение бытия, сковывает его активность. Страх либо мобилизует, либо тормозит человеческое поведение: в страхе может проявиться астеническая реакция (оцепенение и дрожь, полная растерянность), стеническая реакция (паника), или стеническое боевое возбуждение. Страх смерти заставляет человека избегать ситуаций, которые представляют угрозу для его жизни. Страх возникает у человека в связи с опредмечиванием тревожности под влиянием воображаемой или реальной опасности. Он целостно переживается человеком на различных уровнях: фризическом, эмоциональном, когнитивном и поведенческом. Причины возникновения страха также можно классифицировать на несколько групп, среди которых целесообразно выделить: природные, индивидуально-личностные и социокультурные. Страх присущ всем высшим млекопитающим и выполняет необходимую биологическую функцию, связанную с реакцией на положение, вызывающее опасность. Иррациональный страх есть страх человека перед самим собой, перед скрытыми в бессознательном разрушительными импульсами. Страх предстает в качестве одного из механизмов фрормирования социального характера - привития человеку качеств, считающихся необходимыми в данном социуме, и ограничения тех поведенческих проявлений, которые, наоборот, считаются нежелательными.

Ключевые слова: страх, личность, культура, человек, общество, философия, философрская антропология.

Andrey M. Roudenko - Ph.D. of philosophy, associate professor. Institute of service and entrepreneurship (branch) of Don state technical university. Rostov-on-Don, Russian Federation.

Lyudmila E. Kireeva - assistant. Institute of service and entrepreneurship (branch) of Don state technical university. Rostov-on-Don, Russian Federation. 
РуденкоАндрейМихайлович - докторфрилософрскихнаук, доцент. Институт сфреры обслуживания и предпринимательства (филиал) Донского государственного технического университета. г. Ростов-на-Дону, Россия.

Киреева Людмила Евгеньевна - ассистент. Институт сфферы обслуживания и предпринимательства (фрилиал) Донского государственного технического университета. г. Ростов-на-Дону, Россия.

Philosophical anthropology as a philosophical discipline, covering a wide range of problems related to the nature and existence of man in the world, contains an extremely broad subject area. It can provide not only strictly scientific developments (most often having psychological, sociological, socio-psychological, historical and cultural and other bases), but also the data of everyday life, literary works, masterpieces of cinema art, social practices and so on. At the same time, it is important to adhere to those attitudes about man which were formulated by the classicists of philosophical anthropology as a philosophical school. First of all, they are the works of M. Scheler [30, p. 31-96], G. Plesner [20] and A. Gehlen [5, p. 152-202], who, in the conditions of the contemporary historical and cultural situation, convincingly revealed the specifics of man and his place in the world. However, their up to date studies have been greatly expanded and enriched in the works of modern philosophers, revealing certain aspects of human nature. And despite postulating the postmodern era of the end of systematic thinking in philosophy, philosophical and anthropological studies systematically and holistically approaching to the study of human nature, do not lose their relevance, since within the philosophical system of an individual thinker, the study of any human existential, including fear, is done in within its own system of views based on philosophicalanthropological methodology.

Fear came early enough into the object of interest in philosophical anthropology. I.V. Astakhova emphasizes that "... being the most important mode of existence, fear builds up human behavior" [1, p. 78]. This is justified by the fact that, being one of the primary emotions, fear acts as the basic foundation of the orientative reflex arising in the situation of uncertainty. A. A. Sysolyatinhaving the reason behind it calls fear "... a condition for realizing the" seriousness "of human existence" [24, p. 52]. N.A. Berdyaev writes about this: "Fear is the basis of the life in this world ... The body is built to a wide extent for defense. The life is full of the struggle for existence, and it suppose fear ... "[2, p. 285-286]. The philosopher emphasizes that the more perfect and individualized the life, the more threatened it becomes and the greater dangers are exposed.The basic foundations of human's fear are dual: fear, on the one hand, protects a person from danger and promotes the life affirmation of a person, but, on the other hand, fear restricts the human comprehension of existence, enchains his activity.

This position is shared by E.P. Ilyin. He points out that "fear can affect a person differently: in one instance, it can lead to death, in other circumstances - to salvation (escape можнолииспользоватьвданномконтексте?)" [13, p. 31]. At the same time, fear really either mobilizes or breaks human behavior: "Fear is an emotion of focusing on danger and avoiding this danger" [18, p. 134]. In what function will fear appear - mobilizing or disorganizing - depends on the type of person's reaction in an extreme situation [15, p. 340-342].

It can manifest asthenic reaction (stupor and trembling, complete confusion), sthenic reaction (panic), or sthenic fighting excitement (active and conscious activity at the moment of danger on the basis of an instant assessment of the situation). The important regularity in the context of philosophical anthropological research, which is noted by S. Kierkegaard, says that the fear of death compels a person to avoid situations that pose a threat to his life $[17$, p. 151]. It is remarkable that the fear of death takes some time to manifest itself in a person. It appears only with the formation of child's abstract thinking during the period from 5 to 7 years. At this time, the fear of death becomes the leading one. According to the latest 
researches of F.R. Gubaidullina, the appearance of this fear will mark the end of the naive period of a person's life: "The death category of 6-7 years is a life reality that the child must recognize as something inevitable in his life. But the unwillingness to recognize it immediately generates fear"[9, p. 135]. During this period, the reaction of parents to the appearance of this fear with a child is especially important - it depends whether it remains for life or will be partially overcome by a child). In general, many of the more private fears of man is the result of incorrect and unreasonable upbringing. At the same time, there are many methodological difficulties that prevent a deep and holistic study of fear as an emotional phenomenon. V.K. Vilyunas points out that «... the vestiges of the positivist tradition are considered as scientific only empirical cognition and, on the other hand, difficulties in the search for the means of such cognition" [5, p. 9]. Furthermore, this is because of the primary partiality of various forms of ideology and religion to fear, attempts to deny certain values and praise others, using fear as a tool in order to deal with it.

However, the study of fear is further complicated by the fact that "... reliable criteria for fear have not been found " [14, p. 23]. And the study of affective processes has not got yet a clear and recognizable by the majority of scientists terminology, which includes ones concerning the essence and various manifestations of fear. Fear as an internal tension, connected to the expectation of threatening events, arise under the conditions of a threat to the biological and social existence of man. The experience of fear by man was described by Charles Darwin. According to him, fear "leads to instantaneous activation of sight and hearing" [10, p. 659-885]. Fear activates the physiology of the person, which leads to heartthrob, accelerated breathing, blanching of the skin, secreting of "cold" sweat, muscular shivering, parching of the mouth, a tremor and hoarseness in one's voice.

In modern psychology, one of the most authoritative experts in the field of studying emotions, including fear, is the American scientist K. Izard, who comes to the conclusion that fear is the most powerful, toxic and unpleasant emotion. He notes: "The problem of controlling the emotion of fear, especially in the case of having some phobias, is still unresolved in the science of human behavior" [12, p. 293].Fear is a signal of a threat to personal safety.

It often occurs because of emotional contamination or as a result of a cognitive assessment of the situation as potentially dangerous. According to A.M. Rudenko, "among the natural activators of fear, there are: pain and expectation of pain (pain is a good teacher), loneliness (remaining alone, a person often feels a threat to his safety, which gives up as soon as he comes to people), a sudden change of situation or sudden approximation of something, a factor of novelty and sometimes height "[23, p. 390]. Intensive fear always limits the perception and freedom of persons' behavior, who becomes motivated by a single aspiration - to avoid danger. There is no stronger motivation for finding a safe environment of existence than fear. The causes of fear can be classified into several groups. The biological causes of fear are related to the fact that the mechanism of its appearance is associated with a conditioned reflex reaction because of the previously experienced pain or a certain uncomfortable situation, and with the appearance of signals from the external environment that indicates danger to the human body, which are actualize the protective mechanisms of the human psyche and require mobilization of the functioning of the body.

Individual-personal causes of fear are determined due to the typological characteristics of a person. For example, people of a certain type of temperament are affected by phobias as a kind of obsessive fear. While sanguine and melancholic seldom become victims of neurotic fears, melancholics and cholerics are the most vulnerable ones: the first ones due to the weakness of the nervous processes, the second ones - due to excessive excitability.

Sociocultural causes of fear are concerned with those mechanisms of fear that are launched within a particular socio-cultural space. These causes, which create fear, are di- 
rectly related to those social dangers that arise due to a variety of social preconditions. D.G. Vygovskaya singled out such social preconditions as "low spiritual and cultural level, alcoholism, vagrancy, unsatisfactory material status, poor living conditions, problems of dumped kids and orphans, social vulnerability, political and economic instability, unemployment and other factors" [7, p. 233]. All these reasons can lead a person not only to experiencing fear, but also to the fact that the fear of life can become stronger than the fear of death. It is a well-known fact that a combination of factors eggs teenagers on suicide, which, according to the studies of S.M.Kurgansky are concerned "... with family conflicts and ill-being, fear of violence from adults, tactless behavior of certain teachers, conflicts with teachers, classmates, friends, induration and indifference of wider public" [16, p. 243]. Sociocultural causes most often create fears among the crowd of peoples. They often become factors that cramp the development of society, become the cause of its backwardness and degradation. Mass fears are oriented to the situations that develop in the sociocultural space, and their dynamics follow these situations, like any mass phenomenon. The remarkable fact is, for example, that in Russia, the high intensity of fears "... is combined with an extremely low level of the population's ability to self-organize the confrontation from harmful dangers" [6, $p$. 84-89]. This often leads to the emersion of depressive mood and even mood of panic in society, and also serves as an indicator of the existing socio-cultural crisis.

Researches of D.N. Razuvaeva shows that social fears most often begin in humans in adolescence and they are manifested in fear of "not being oneself ", fear of failure, condemnation and punishment, fear of physical deformities, fear of loneliness, fear of hopelessness and impossibility of self-realization [21, p. 28]. At the same time, one of the decisive influences on the experience of social fears is the specificity of family relations: lack of mutual understanding, emotional strangeness, interpersonal tension. All these factors serve for increasing the number of social fears.

At the same time, some researchers (for example, J. Bowlby) believe that "... many cultural determinants of fear on their closer examination may be associated with natural determinants, disguised by various forms of misinterpretation, rationalization or projection" [11, p. 183]. Thus, a fear of thieves or ghosts can be a rationalization of a fear of darkness, and a fear of falling lightning can be a rationalization of a fear of thunder. At the same time, it seems to us, that natural and socio-cultural causes of fear should still be differentiated.J. Bowlby himself identifies two groups of fear causes: natural stimuli (sudden change of the stimulus of loneliness, height, subitaneous approximation, pain, unfamiliarity, etc.) and arbitrary stimuli (darkness, unfamiliar objects, unfamiliar people, fear of animals, etc.) [33]. If the inherited determinants of fear are laced with situations that have a really high degree of danger, (then) the derivatives are more influenced by the culture and context of the situation. At the same time, the scientist emphasizes that the most important reason of fear for a person is loneliness.In the twentieth century, the study of fear, (as well as) in terms of philosophical anthropology, was greatly influenced by psychoanalysis, which dates back to $Z$. Freud.

Z. Freud paid much attention to the study of fear and anxiety. Among his works there is an independent study specifically devoted to fear [25, p. 243-321]. In this study, the scientist comes to a series of interesting conclusions regarding fear. He points out that human fear has "... first of all, the specific nature of the unpleasant things, on the second hand, the reaction of exclusion and, thirdly, the perception of these moments" [25, p. 284]. Freud considers that fear is subsistent to all higher mammals and fulfills the necessary biological function associated with reacting to a situation that causes danger. Moreover, as noted by $Z$. Freud, "... it is regularly reproduced when such a state is created again" [25, p. 285]. At the same time, Freud sets the goal of understanding where the individual differences in the experience of fear originate(appear) under the panhuman (universal) character of various dangers, and also in the ability to control it and subordinate it to the normal course of psych- 
ic life. Freud had the following answer to this question: that different people use the psychological mechanisms of protection differently and, above all, the mechanism of repression: "If I managed to protect myself from a dangerous attraction, for example, through the process of displacement, then this I braked and it harmed this part of It, I should at the same time give it and a certain dole of independence and give up often my own domination over it"[25, p. 303].

However, it is not the best way to get rid of fear, which is in fact is an attempt to escape, because it also generates phobias as obsessive fears that affect a person in situations of irrelevant danger. According to J. Brown, "... a phobia expressed in the fear of knives or a specific exaggerated aversion to all forms of aggressive self-expression can mask deeply seated destructive desires, and a vehement fear of being sexually assaulted may conceal lust" [4, p. 16]. Such compromise solutions are unrealistic and inconvenient, but they "... serve as a direct function of preserving the individual's untouched self-esteem in situations "being who is who» interprets as dangerous, which enables him to remain subsumed in primitive desires that are reinterpreted in terms of fear and disgust"[4, p. 16]. For that matter, the factors which give rise to this sort of fears are simultaneously the factors that generate neuroses. At the same time, Freud notes that there are three such factors: the first one - biological (arises as a result of helplessness during the intrauterine existence of the child), the second - phylogenetic (due to the ratchet effect of humans libido, because "... after the first early flush in the period up to the five-year age, there comes an energetic break in development, after which, with the approaching of maturity, it begins again, proceeding from infantile embryos "[25, p. 305] and the third - psychological (protection by consciousness from the instincts of the unconscious and rendering them as dangers).

Further development of the problems of fear in the psychoanalytic and philosophicalpsychoanalytic tradition was associated with the names of K. Horney and E. Fromm. These authors gave culturological and social character to the works of $Z$. Freud about fear and anxiety, enrolled a person in a certain context, contributing or limiting the development of fears.

For E. Fromm, unlike Freud, sexuality was by no means the only and dominant force which determines a person. According to Fromm, fear appears as one of the mechanisms for the creation of a social character - the inoculation of qualities that are considered as necessary in a given society, and the limitations (restrictions) of those behavioral manifestations that, on the contrary, are considered undesirable [26, p. 3-366]. The society forms (creates) the personality, contributing at the same time to the formation of certain fears: the fear of standing out from the masses, the fear of being different. In addition, the peculiarities of the individual biography, conditioned by the specifics of the socialization of the individual in a specific life situation, can give rise to specific fears: for example, fear of making independent decisions, fear of new and unknown, fear of being abandoned, fear of other people.Modern society, in principle, gives a person the opportunity to be relatively free, but the person, as rightly points out E. Fromm, often prefers to get rid of it, because it is frightening to be free. It is frightening because in the conditions of individualistic Western culture the back side of freedom is a feeling of loneliness. E. Fromm writes about this: " just then, when the formation of a modern man began, more clearly than earlier or later, the dual nature of freedom manifested itself ... On the one hand, there was an increasing independence of a person from outside authorities, on the other hand - his isolation, and as the result of this confrontation - a developing sense of insignificance and impotence "[26, p. 305].

This thought repeats many times by $\mathrm{E}$. Fromm. He constantly emphasizes that "a person becomes more independent, self-confident, self-critical, but at the same time person feels lonely and in complete isolation, and it really worries him and even frightens" [26, $p$. 129]. At the same time, the philosopher is convinced that man is a being which exists "in the adventure of self-development," creating himself. If a person embodies his nature freely, he 
does not have the painful fears associated with negative social influence. However, the open nature of man poses itself certain problems for him. The almost complete lack of instinctive behavior for a person and the presence of his mind puts him into unique for the animal world situation of openness and choice of possible behavior. These same features impose to a person a need for a system of orientation: a system of representations and norms, by which he could guide his behavior. Culture and social institutions satisfy to this need, but not always with due efficiency. And very often the works of the human mind turn against man, deforming his nature.

This is clearly seen in the example of religions that E. Fromm divides into humanistic and authoritarian [27, p. 143-221]. Both those and others offer the person a solution to the meaningful problem. But humanistic religions (like Buddhism, early Christianity, Judaism of the time of the prophets) do this by appealing to the disclosure of human abilities, while the others (Christianity in its bureaucratized form, Islam) inspires fear of punishment for disobeying authority. Under the religion E. Fromm understands any system of ideas relating to problems of the worldview. It includes secular ideologies (communism and fascism).Studying the problem of fear and anxiety, K. Horney also shows the importance of culture for the formation of fears [28]. She (It) distinguishes between normal and neurotic fears.Normal fears are associated with certain objectively existing threats, both natural and socio-cultural, generated by various negative social phenomena: poverty, for example, or the policy of the authorities, as well as certain cultural meanings (fear of breaking taboos, etc.).

Thus, culture and society are recognized as the source of many fears. On the other hand, they also offer mechanisms to overcome these fears.Neurotic fears are represented by something else. The neurotic suffers from fears more than the normal (i.e., entered in the social and cultural context) person. Neurotic fears are created by internal conflicts, the individual's reaction to the demands that society presents to him. Seeking to follow requirements that are in contradiction with the requirements of his inner nature, a person is forced to wear a mask and pretend. The reaction to this situation is neurosis, which is based on an unconscious sense of guilt. What, in K. Horney's opinion, are the signs of fears that cause their specific neuroticization?

First, the conditions of life in any culture form certain fears. A neurotic personality not only shares the fears inherent in all people belonging to a given culture, but because of the specifics of his personal biography, his individual life path, which are related to the general conditions, he experiences anxieties and fears qualitatively or quantitatively different from the general cultural fears. Secondly, in order to overcome the fears inherent in this culture, in the same culture there are specific methods of protection (rituals, taboos, customs). An ordinary, normal person uses the opportunities to overcome the fears provided by his culture. According to K. Horney, "he suffers no more than it is inevitable in his culture" [28, p. 35]. The neurotic personality, however, is predominantly suffering more than the ordinary person. K. Horney singles out another significant sign of neurosis, which consists in the presence of a conflict of antagonistic tendencies, the presence of which the neurotic does not realize, and in respect of which he involuntarily would like to find compromise solutions. The role of the social environment, the specifics of education in the formation of fears and neurotic reactions is analyzed in the $\mathrm{E}$. Ericksons' theory of socialization. He drew attention to the fact that "successive civilizations, exploiting suitable syndromes of infantile fears, raise the corresponding values of the child's ego to the level of higher collective aspirations" [31, p. 154].

For example, religion gives an organized form to the conflict between trust and anger, collectively cultivating trust in the form of faith and giving evil the form of sin. And it is fixed in the form of a social institution that is going through its historical time and exists in the context of intercivilizational and intergenerational space. Erikson's research data, according to 
our reckoning, make a valuable contribution to understanding the genesis and nature of human fear.The problem of the creation of various fears which is based on the experience of socialization and children's experience was also touched upon by other psychologists of the twentieth century. O. Rank, for example, believed that the first source of fear and anxiety is the trauma of birth. He is convinced that "the fear of birth underlies in the bases of any kind of fear, and any pleasure, after all, tends to restore the primary intra-uterine pleasure" $[22$, p. 26]. O. Rank writes that "... the mechanism of the appearance of fear, which later returns to phobic patients in a practically unchanged form (claustrophobia, fear of passage through a railway tunnel, etc.), can be understood as an unconscious reproduction of the fear of birth" [25]. Neurosis, from his point of view, is the result of an internal conflict between a person's desire to return to a state of prenatal harmony and a memory of the horror of birth.In existential psychology, neurotic fears and phobias are associated with a certain damage to the world picture that a person has. R. May, one of the largest representatives of this area of psychology, writes: "We ... can not progress in our understanding of fear if we consider it only as a psychopathological symptom" [19].

In other words, in order to understand the nature of fear, one should not separate "fear" from "peace." Fear always occurs when the world becomes unstable or threatens to disappear.In existential psychology, the problem of man's loss of his own world is considered. According to L. Binswanger, the creator of existential analysis in psychology, beingin-the-world includes three aspects [3]: the physical world, which belongs not only to man, but to all living beings; the social world, the sphere of interaction between people; the world of self (in the bodily and spiritual aspects), inherent only to man. All aspects of being-in-theworld must be in a harmonious unity. The world of self is the basis for the interaction of all aspects. Refusal of realization of their goals under the influence of circumstances leads to negative consequences.

Swiss psychiatrist, representative of existential psychotherapy M. Boss [32] gives an example of the consequences of "failure", which is typical for a melancholic patient: "The fact that the melancholic patient could not openly and responsibly accept all the opportunities for attitudes toward the world which can compose his own the true I, correlates with his whole existence. Accordingly, such existence is not independent, it constantly becomes a prey to the demands, expectations and desires of others. Such patients try to live in accordance with these alien expectations, in order not to lose the protection and love of those who surround them "[29]. It should be mentioned that it is generate a sense of existential guilt in the melancholic and constant self-blame. His symptom load will vary depending on how he cannot live in word of his openness, in the light in which everything that happens can manifest itself in its entirety.Thus, the philosophical anthropological analysis of fear and anxiety, based on psychological developments, has been enriched, first of all, by studying the specific causes of fears and anxieties, which allow us to take a fresh look at that understanding of the fear that existential psychology forms.

\section{Лumepamypa}

1. Астахова И.В. Страхи и фобии в современном обществе: взгляд ученого и практика // Экономика и социум: современные модели развития. 2011. № 1.

2. Бердяев Н.А. Экзистенциальная диалектика божественного и человеческого // О назначении человека. М.: Республика, 1993.

3. Бинсвангер Л. Бытие-в-мире. М.: Ювента, СПб.: Ленато, 1999.

4. Браун Дж. Психология Фрейда и постфрейдисты /Пер. с англ. А.М. Руткевича. M.: REFL-book; Киев: Ваклер, 1997.

5. Вилюнас В.К. Психология эмоций. СПб.: Питер, 2007. 
6. Волкова E.A. Страхи россиян как индикатор общественной напряжённости / Е.А. Волкова, А.О. Егорова // Научный вестник Воронежского государственного архитектурно-строительного университета. Серия: Социально-гуманитарные науки. 2016. № 1 (9).

7. Выговская Д.Г. Страхи в российском обществе: роль, ффункции, значение // Вестник Южно-Российского государственного технического университета (Новочеркасского политехнического института). Серия: Социально-экономические науки. 2012. № 5.

8. Гелен А. О систематике антропологии // Проблема человека в западной философиии: Переводы. М.: Прогресс, 1988.

9. Губайдуллина Ф.Р. Детские страхи // Дошкольное образование: опыт, проблемы, перспективы развития. 2016. № 2 (9).

10. Дарвин Ч. Выражение эмоций у животных и человека // Собрание сочинений в 9-ти томах. М.: Изд. АН СССР, 1953. Т. 5.

11.Дорофреева Г.А. Страхи: определение, виды, причины // Известия ЮФУ. Технические науки. 2002. № 5 (28).

12. Изард К. Психология эмоций. СПб: Питер, 2006.

13. Ильин Е.П. Психология страха. СПб.: Питер, 2017.

14.Корнеева Т.П. Особенности психологического консультирования клиентов с фобиями и страхами /Т.П. Корнеева, А.Ю. Заболотнева// Поиск (Волгоград). 2016. № 1 (3).

15. Косолапов О.М. Возникновение страхов в экстремальных ситуациях: типы реакций на страх и стадии развития // Проблемы обеспечения безопасности при ликвидации последствий чрезвычайных ситуаций. 2012. № 1.

16. Курганский С.М. Когда страх перед жизнью сильнее страха смерти // Народное образование. 2011. № 5.

17. Кьеркегор С. Повторение (Опыт экспериментальной психологии Константина Констанция). М.: Лабиринт, 1997.

18. Мухина В., Басюк В. Инициации подростков как условие личностного роста: проведение инициаций страхом // Развитие личности. 2011. № 1.

19.Мэй Р.Экзистенциальная психология // [Электронный ресурc]. URL: http://ezolib.ru/5747.html

20. Плеснер Г. Ступени органического и человек: Введение в фрилософрскую антропологию / Пер. с нем. М.: «Российская политическая энциклопедия» (POCСПЭН), 2004.

21. Разуваева Д.Н. Социальные страхи в подростковом возрасте // Научный форум. Сибирь. 2016. Т. 2. № 1.

22. Ранк О. Травма рождения и ее значение для психоанализа.М.: Когито-Центр, 2009.

23. Руденко А.М. Психология. Ростов-на-Дону: Феникс, 2012.

24. Сысолятин А.А. Страх и признание: антропологические аспекты исследования «общества потребления» // Известия Уральского федерального университета. Серия 3: Общественные науки. 2014. Т. 128. № 2.

25. Фрейд 3. Страх // Сборник / Пер. с нем. Я.М. Когана, М.В. Вульфра. Мн.: Попурри, 1998.

26. Фромм Э. Бегство от свободы // Бегство от свободы; Человек для себя / Пер. с англ. Д.Н. Дудинского. Мн.: Попурри, 2000.

27. Фромм Э. Психоанализ и религия // Сумерки богов. М.: Политиздат, 1990.

28. Хорни К. Невротическая личность нашего времени. Самоанализ. М.: ПрогрессУниверс, 1993. 
29.Холл К., Гарднер Л. Теории личности. М., 1997.[Электронный ресурc]URL: http://psylib.org.ua/books/holli01/txt08.htm

30. Шелер М. Положение человека в Космосе // Проблема человека в западной философии: Переводы / Сост. и послесл. П. С. Гуревича; общ. ред. Ю. Н. Попова. М.: Прогресс, 1988.

31. Эриксон Э.Х. Детство и общество. СПб.: Университетская книга, 1996.

32. Boss M. Psychoanalysis and Dascinanalysis. N.Y.: Basic Books, 1963.

33. Bowlby J.Attachment and Loss. Separation, anxiety and anger. Volume II. London: Hogarth.

\section{References}

1. Astakhova I.V. Fears and phobias in modern society: a scientist's view and practice // Economics and society: modern models of development. 2011. No 1.

2. Berdyayev N.A. The existential dialectic of the divine and the human // About the role of man. M.: Republic, 1993.

3. Binswanger L. Being-in-the-world. M.: Juventa, St. Petersburg.: Lenato, 1999.

4. Brown G. Freud's psychology and post-Freudians / Trans. from English. M., 1997.

5. Vilyunas V.K. Psychology of emotions. St. Petersburg: Peter, 2007.

6. Volkova E.A. Fears of Russians as an indicator of social tension // Scientific bulletin of the Voronezh State Architectural and Construction University. Series: Social and Humanities Sciences. 2016. No. 1 (9).

7. Vygovskaya D.G. Fears in Russian society: role, functions, value // Bulletin of the South-Russian State Technical University (Novocherkassk Polytechnic Institute). Series: Socio-economic sciences. 2012. No 5.

8. Gelen A. About the systematics of anthropology // Problem of man in western philosophy: Translations. Moscow: Progress, 1988.

9. Gubaidullina F.R Children's fears // Preschool education: experience, problems, development prospects. 2016. No 2 (9).

10.Darwin Ch. Expression of emotions in animals and man // Collected works in 9 volumes. Moscow: Ed. AN SSSR, 1953. Vol. 5.

11. Dorofeeva G.A. Fears: Definition, types, causes // Bulletin SFU. Technical science. 2002. No 5 (28).

12. Izard K. Psychology of emotions. St. Petersburg: Peter, 2006.

13. Ilyin E.P. Psychology of fear. St. Petersburg: Peter, 2017.

14. Korneeva T.P. Features of psychological counseling of clients with phobias and fears // Search (Volgograd). 2016. No. 1 (3).

15. Kosolapov O.M. The appearing of fears in extreme situations: the types of reactions to fear and stages of their development // Problems of safety ensuring in the emergency relief operation. 2012. No 1.

16. Kurgansky S.M. When the fear of life is greater than the fear of death // Public education. 2011. No5.

17. Kierkegaard S. Repetition (Experiment of experimental psychology of Constantius II). M.: Labirint, 1997.

18. Mukhina V., Basyuk V. Initiation of adolescents as a condition of personal growth: initiating fears // Personal development. 2011. No 1.

19. May R. Existential psychology // [Electronic resource]. URL:http://ezolib.ru/5747.html 
20. Plesner $G$. The steps of the organic and man: Introduction to philosophical anthropology / Trans. from German. Moscow: The Russian Political Encyclopedia, 2004.

21. Razuvaeva D.N. Social fears in adolescence // Scientific forum. Siberia. 2016. Vol. 2. No. 1.

22. Rank O. Birth trauma and its significance for psychoanalysis. Moscow: KogitoCenter, 2009.

23. Rudenko A.M. Psychology. Rostov-on-Don: Phoenix, 2012.

24. Sysolyatin A.A. Fear and its recognition: anthropological aspects of the study of the "consumer society" // Bulletin Ural Federal University. Series 3: Social Sciences. 2014. No 2.

25. Freud Z. Fear // The collection / Trans. from German. Y.M. Kogan, M.V. Wulf. Minsk, 1998.

26. Fromm E. Escape from freedom / Flight from freedom; Man for himself / Trans. from English. D.N. Dudinsky. Minsk., 2000.

27. Fromm E. Psychoanalysis and religion / Twilight of the gods. Moscow: Politizdat, 1990.

28. Horney K. Neurotic personality of our time. Introspection. Moscow: ProgressUniversus, 1993.

29. Hall K., Gardner L. Theories of personality. M., 1997.[Electronic resource]URL: http://psylib.org.ua/books/holli01/txt08.htm

30. Scheler M. The position of man in the Space // The problem of man in Western philosophy: Translations. Moscow: Progress, 1988.

31. Erickson E.H. Childhood and society. SPb.: University Book, 1996.

32. Boss M. Psychoanalysis and Dascinanalysis. N.Y .: Basic Books, 1963.

33. Bowlby J. Attachment and Loss. Separation, anxiety and anger. Volume II. London: Hogarth. 